\title{
Computational estimation of calcium fluxes in isolated magnocellular neurons
}

\author{
S Kortus ${ }^{1,2,3}$, G Dayanithi ${ }^{3,4}$, M Zapotocky $^{1,2^{*}}$ \\ From 24th Annual Computational Neuroscience Meeting: CNS*2015 \\ Prague, Czech Republic. 18-23 July 2015
}

Current optical methods based on fluorescent indicators permit to measure the intracellular calcium concentration with a high temporal resolution. To analyze the physiological mechanisms that underly the calcium dynamics, however, knowledge of the calcium fluxes into and out of the cell is needed. Here we present a method that permits to separately estimate the influx and clearance rates, based on the measurement of $\mathrm{Ca}^{2+}$ concentration during a series of depolarization-evoked calcium transients. We apply this method to investigate calcium clearance mechanisms in isolated magnocellular neurons of the rat supraoptic nucleus.

In the simplest case, we assume that the cytoplasmic $\mathrm{Ca}^{2}$ + concentration during the transient is governed by a time-dependent influx $J_{\text {influx }}(\mathrm{t})$ through voltage-gated Calcium channels and by an outflux $J_{\text {clearance }}$ that depends only on the instantaneous calcium concentration $\left[\mathrm{Ca}^{2+}\right](\mathrm{t})$ :

$$
d\left[\mathrm{Ca}^{2+}\right] / d t=J_{\text {influx }}(\mathrm{t})-J_{\text {clearance }}\left(\left[\mathrm{Ca}^{2+}\right] .\right.
$$

To separate the two fluxes, we first estimate the clearance function $J_{\text {clearance }}\left(\left[\mathrm{Ca}^{2+}\right]\right)$. Near the end of the transient, $J_{\text {clearance }}$ dominates over $J_{\text {influx }}$, and $J_{\text {clearance }}$ may be obtained directly as the measured $\mathrm{Ca}^{2+}$ decay rate [1]. In contrast, near the peak of a transient the two fluxes are comparable, and $J_{\text {clearance }}$ therefore significantly exceeds $-\mathrm{d}\left[\mathrm{Ca}^{2+}\right] / \mathrm{dt}$. However, in this case the clearance rate obtained from a higher transient can be used as a good estimate. If the assumption of Eq.1 is satisfied, the clearance function is obtained as the envelope of the recorded return curves in the $\mathrm{d}[\mathrm{Ca} 2+] / \mathrm{dt}$ vs. $[\mathrm{Ca} 2+]$ plot. The calcium influx rate $J_{\text {influx }}(\mathrm{t})$ during each transient is then estimated by substracting $J_{\text {clearance }}\left(\left[\mathrm{Ca}^{2+}\right](\mathrm{t})\right)$ from the

\footnotetext{
* Correspondence: zapotocky@biomed.cas.cz

'Institute of Physiology of the Czech Academy of Sciences, Prague, Czech Republic

Full list of author information is available at the end of the article
}

measured rate $\mathrm{d}\left[\mathrm{Ca}^{2+}\right] / \mathrm{dt}$. We tested the adequacy of this procedure using surrogate calcium dynamics data.

For cells in which the endoplasmic reticulum (ER) noticeably contributes to the calcium transient [2], the clearance function $J_{\text {clearance }}$ is not solely dependent on the cytoplasmic calcium concentration, as was assumed above. In this case, the method described above can still be applied to experiments performed in presence of Thapsigargin or cyclopiazonic acid (CPA), to avoid release or uptake of $\mathrm{Ca}^{2+}$ by the ER. Comparison of the estimated fluxes from the experiments with and without Thapsigargin/CPA can be used to investigate the ERdependent calcium fluxes. We apply this method to freshly isolated magnocellular neurons, in which we used Fura$2 \mathrm{AM}$ to measure the cytoplasmic $\left[\mathrm{Ca}^{2+}\right]$ during depolarization-evoked $\mathrm{Ca}^{2+}$ transients of various amplitudes and durations; depolarization was induced [3] by changing the external $\mathrm{K}^{+}$concentration.

Our method of estimating the $\mathrm{Ca}^{2+}$ fluxes may be used also in other cell types to help characterize the contribution of individual mechanisms to calcium dynamics.

\footnotetext{
Authors' details

${ }^{1}$ Institute of Physiology of the Czech Academy of Sciences, Prague, Czech Republic. ${ }^{2}$ Institute of Biophysics and Informatics, First Faculty of Medicine, Charles University in Prague, Prague, Czech Republic. ${ }^{3}$ Institute of Experimental Medicine, Czech Academy of Sciences, Prague, Czech Republic. ${ }^{4}$ INSERM U710/EPHE, Université Montpellier 2, Montpellier, France.

Published: 18 December 2015

References

1. Fierro L, DiPolo R, Llano I: Intracellular calcium clearance in Purkinje cell somata from rat cerebellar slices. Journal of Physiology 1998, 510(2):499-512.

2. Gilon P, Arredouani A, Gaill P, Gromada J, Henquin JC: Uptake and release of $\mathrm{Ca}^{2+}$ by the endoplasmic reticulum contribute to the oscillations of the cytosolic $\mathrm{Ca}^{2+}$ concentration triggered by $\mathrm{Ca}^{2+}$ influx in the electrically excitable pancreatic B-cell. J.Biol.Chem 1999, 274:20197-20205.
} 
3. Harasztosi C, Por A, Rusznak Z, Szucs G: Removal of $\mathrm{Ca}^{2+}$ following depolarization-evoked cytoplasmic $\mathrm{Ca}^{2+}$ transients in freshly dissociated pyramidal neurones of the rat dorsal cochlear nucleus. Brain Research 2002, 930:123-133.

doi:10.1186/1471-2202-16-S1-P299

Cite this article as: Kortus et al:: Computational estimation of calcium

fluxes in isolated magnocellular neurons. BMC Neuroscience 201516

(Suppl 1):P299.

Submit your next manuscript to BioMed Central and take full advantage of:

- Convenient online submission

- Thorough peer review

- No space constraints or color figure charges

- Immediate publication on acceptance

- Inclusion in PubMed, CAS, Scopus and Google Scholar

- Research which is freely available for redistribution

Submit your manuscript at www.biomedcentral.com/submit

C Biomed Central 